〈原 著〉

血液培養ガイドラインによる消毒方法は鼠径部からの血液培養の污染率を低減する 一特定医師実施の血液培養採血検体による污染率の検証一

高橋 賢史

\title{
The Disinfection Method Recommended in the Guideline Reduced Contamination Rate in Blood Cultures from the Groin Area - Evaluation using Blood Culture Performed by One Skillful Physician
}

Satoshi TAKAHASHI

Izumo Medical Cooperative The Izumo-Shimin Hospital, Department of Family Medicine

(2020 年 4 月 21 日受付 $\cdot 2020$ 年 10 月 12 日受理)

要 旨

目的：血液培養のガイドラインでは, 陽性率 $5 \sim 15 \%$, 污染率 $2 \sim 3 \%$ 以下が適切とされる. 鼠径 部からの採血はコンタミネーションが増えると言われているが, 当院では圧倒的に鼠径部からの採 血で行う事が多い. 2016 年よりガイドラインに準じた消毒方法を遵守し，それにより鼠径部から のコンタミネーションが軽減できるかどうかを検証した，個人間の手技の違いを排除するため，検 証にあたり特定の 1 名の医師が採血した検体のみを取り上げた.

方法：2014 年からの 5 年間, 当院において提出した血液培養のうち, 1 名の医師が実施した血液 培養を対象とした記述統計，ならびに過去起点コホートスタディを実施した.

結果： 800 セットを分析し, 採血部位は鼠径部が $94.4 \%$ で上肢が $5.6 \%$, 複数セット採取率は $99.0 \%$ であった．ガイドラインに準じた消毒方法へ変更した 2016 年より鼠径部採血の陽性率，污染率と も低下し, 2016 から 2018 年における鼠径部採血の污染率は 1.7\% であった. 上肢採血の污染率は $0 \%$ であったが有意差は見られなかった。

考察：鼠径部からの血液培養採血はコンタミネーションが増える傾向はあるが，ガイドラインに 準じた適切な皮膚消毒が行われれば適正範囲内の污染率は可能となると考えられる.

Key words：血液培養, コンタミネーション, 污染率, 採血部位, 鼠径部

\section{1. 序文}

血液培養は感染症診療において菌血症を診断するため に重要な意義を持っている。しかし検体採取時における 皮膚常在菌のコンタミネーションは, 不要な検査や抗菌 薬の追加につながる可能性があり, これを防ぐために徹 底した質管理が必要と言える。血液培養のガイドライン では，採血時にまず穿刺部位をアルコールで皮膚消毒を 行い, 次いでヨード剤やクロルヘキシジンを用いて皮膚

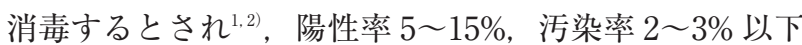
が適切とされている ${ }^{1,2)}$. 近年, 日本においても血液培養 の陽性率・污染率に関する研究が実施されており ${ }^{3 \sim 8)}$,

出雲医療生活協同組合出雲市民病院家庭医療科
血液培養検体採取プロセスの評価・質向上に対する関心 の高さを伺える.

血液培養の採血部位は一般的に上肢からの採血が基本 とされている21. それに対し鼠径部からの採血はコンタ ミネーションが増えると言われており ${ }^{6 \sim 8)}$, 近藤らはそ れを裏付けるデー夕を報告している ${ }^{8)}$.一方当院では，血 液培養採血部位は鼠径部を選択する事が圧倒的に多い. その中, コンタミネーションを極力抑えるべく 2016 年 よりガイドラインに準じた消毒方法を遵守した．それま ではポビドンヨード綿球で 2 回皮膚消毒という方法とし ていたが，2016 年 1 月より皮膚消毒前のアルコール綿 清拭を開始し，同年 11 月より血液培養採血時の皮膚消 毒液をポビドンョードから $1 \%$ クロルヘキシジンへ変更 
した．それにより鼠径部からの血液培養コンタミネー ションが軽減できるかどうかを検証する必要があると考 えられた。

血液培養採血時のコンタミ傾向は実施者による皮膚消 毒手技の違いに影響されるため ${ }^{1)}$, 個々の医師間での手 技的な差を排除してより正確に検討する事を目的に, 当 院で実施した血液培養のうち特定の医師が採血したもの のみを取り上げて検証を行った。

\section{2. 方 法}

\section{研究デザイン}

記述統計，ならびに異なる消毒方法間における 2 群間 比較

\section{対 象}

2014 年 1 月から 2018 年 12 月の 5 年間, 当院 (180 床 : 一般病床 32, 地域包括ケア病床 88, 障害者病床 602017 年度外来患者数 : 150.4 人/日, 同入院患者数 : 150 人/ 日）において提出した血液培養のうち，A医師がオー ダーした血液培養全症例を対象とした. ただし, 透析シャ ント血管, カテーテル，透析回路から採血した検体，な らびに記録不十分のものは除外とした.

A 医師は感染症専門医ではない卒後 15 年の中堅医師 である，血液培養に関する特別なトレーニングは受けて いないが，2014 年時点で血液培養採血について充分な 経験を既に有しており，研究期間を通じて手技のばらつ きが当院所属医師の中で最も少ない医師として, 今回の 検証においての人選とした.

\section{血液培養検体採取の方法}

A 医師自身が血液培養採血を実施した．消毒方法は 以下の通りである. 2016 年からはガイドラインに準じ た消毒方法へ変更した.

(1)2016 年以前：ポビドンヨード綿球を用いて，1 回目 は皮膚表面を強く擦過する形で行い, 2 回目は同心円状 に消毒を実施した。

(2)2016年初めから 2016 年 10 月まで：まず単包式 $70 \%$ エ夕ノール綿で血液採取部位皮膚表面の污れが十 分に落ちるまで繰り返し擦過し, 次いでポビドンヨード 綿球を用いて, 1 回目は皮膚表面を強く擦過する形で行 い, 2 回目は同心円状に消毒を実施した。

(3)2016 年 11 月以降：まず単包式 70\%エタノール 綿 で血液採取部位皮膚表面の污れが十分に落ちるまで繰り 返し擦過し, 次いで $1 \%$ クロルヘキシジングルコン酸塩 エタノール消毒液スティックを用いて, 1 回目は皮膚表 面を強く擦過する形で行い, 2 回目は同心円状に消毒を 実施した。

皮膚消毒後, 滅菌手袋を装着し 1 回 $20 \mathrm{~mL}$ の採血を基 本的に行った．採取した検体は $\mathrm{BD}$ バクテック ${ }^{\mathrm{TM}}$ 血液培 養ボトル（日本ベクトン・ディッキンソン株式会社, 東
京）に混注し, 培養検査は外部委託（株式会社エスアー ルエル，東京）した。採血部位の選択は実施医の裁量で 判断し, 鼠径部からは主に大腿静脈（静脈穿刺困難時は 大腿動脈），上肢は橈側皮静脈・正中皮静脈を穿刺した。

\section{データ収集と分析}

対象患者の電子カルテより ID, 採血年月日, 年齢, 性 別, 採血部位, 検出菌株名を抽出し, 抽出データに, 複 数セット採取できたか, 培養陽性であったか, 污染があっ たか，のラベルとサンプルナンバーを付けた後 ID は削 除し，データは連結不可能匿名化した。抽出情報より， 複数セット採取率, 陽性率, 污染率を算出し, 単純解析, 多変量解析を行った。年齢は中央值と四分位範囲で表示 した。

統計解析ソフトは EZR（Ver, 1.33 for windows）を 使用した9).

\section{定 義}

- 陽性率：(菌体検出セット数/総提出セット数) $\times 100$ （\%）で表した.

・コンタミネーション：同日複数セット採取のうち, coagulase negative Staphylococcus, Propionibacterium acnes, Micrococcus, viridans group streptococci, Corynebacterium, Bacillus, Clostridium perfringens が 1 セットのみ採取された場合とした ${ }^{10)}$.

・污染率：(コンタミネーションセット数/総提出セッ 卜数） $\times 100 （ \%)$ で表した。これは血液培養検体の複 数セット採取率が $90 \%$ 以上の時に有効とされる ${ }^{10)}$.

\section{倫理的配慮}

本調査は既に実施された医療行為の情報のみを利用し， 研究協力者に対する新たな侵襲は加えられず，診療上の 不利益も生じない. 収集した情報は連結不可能匿名化し た形でデー夕を保存し, 結果公表にあたっても個人が特 定されるような情報は公開しない. 以上を踏まえ, 研究 協力同意に関してはオプトアウトを用いる事とし，個別 のインフォームドコンセント取得は省略した ${ }^{11}$.

本研究は, 出雲市民病院院内倫理委員会より実施承認 を得た（承認番号：No.17-04, No.18-05).

\section{3. 結 果}

期間内に当院で実施した血液培養総数は 3707 セット であった. そのうち今回対象とした A 医師のオーダー は 1162 セット (31\%) で，除外基準に該当する 362 セッ 卜 (透析シャント血管, カテーテル, 透析回路検体 : 359 セット，部位記録不十分：3 セット）を除く 800 セット を分析対象とした．研究対象症例の全体像を表 1 に示 す。採血部位は鼠径部が $94.4 \%$, 複数セット採取率は $99.0 \%$, 陽性率は $23.0 \%$, 污染率は $5.2 \%$ であった。 5 年 間で検出された菌株数は 210 株. 内訳は頻度の高い順に Escherichia coli (33\%), Staphylococcus epidermidis 
(9\%), coagulase negative Staphylococcus (CNS) (7\%) であった（図 1).

次いで採血部位による比較結果を表 2 に示す。年齢 中央值は鼠径部群 86 歳, 上肢群 68 歳であり有意に鼠径 部群が高かった（P<0.01, Mann-Whitney 検定). 性別 に有意な違いは無く $(\mathrm{P}=0.43$, Fisher 検定 $)$, 污染率は 鼠径部群で $5.6 \%$, 上肢群で $0 \%$ であった. 尚, 鼠径部 群で污染率が高い傾向であったが有意差は認めず（P= 0.16, Fisher 検定), 年齢, 性別を加味したロジスティッ

表 1 結果のサマリ

\begin{tabular}{llc}
\hline 総数 & & 800 \\
年齢 & & $85[79,90]$ \\
性別 & 男性 & 427 \\
& 女性 & 373 \\
採血部位 & 上肢 (\%) & $45(5.6)$ \\
& 鼠径部 (\%) & $755(94.4)$ \\
複数セット (\%) & & $792(99.0)$ \\
検出菌株数 & & 210 \\
陽性セット数 & & 184 \\
陽性率 (\%) & & 23.0 \\
污染セット数 & & 42 \\
污染率 (\%) & & 5.2 \\
\hline
\end{tabular}

年齢は中央値と四分位範囲（括弧内）を表す.
ク回帰分析を実施したが有意差は認めなかった（P= 0.98).

鼠径部採血群においてガイドライン遵守の消毒方法を 導入した 2016 年〜2018 年と，それ以前の 2014 年〜2015 年の 2 群に分けて比較した結果を表 3 に示す。年齢の 小さな差（1 歳）を除けば患者背景には差は無く，陽性 率，污染率とも顕著に低下していた $(\mathrm{P}<0.001$, カイ 2 乗検定, Fisher 検定). 尚, 2016 年, 2017 年, 2018 年 では消毒液に違いがあるが，表 4 に示すように陽性率， 污染率に有意差は認めなかった $(\mathrm{P}=0.286, \mathrm{P}=0.621$, Fisher 検定).

更に，2016 年〜2018 年の検体において，鼠径部採血 群と上肢採血群の 2 群で比較した結果を表 5 に示す。患 者背景では年齢が鼠径部群で有意に高く, 上肢群に比較 して大きな差を認めた。性別や複数セット採取率に差は 無かった。陽性率では上肢群 $0 \%$ に対して鼠径部群 $18.6 \%$ と有意に高かった（P<0.05, Fisher 検定 $)$ 。污染 率では上肢群 $0 \%$ に対して鼠径部群 $1.7 \%$ であるが有意 差は認めず $(\mathrm{P}=1.000$, Fisher 検定 $)$, 年歯令, 性別を加 味したロジスティック回帰分析でも有意差は認めなかっ た $(\mathrm{P}=0.994)$.

尚, 2016 年から 2018 年に検出された細菌を図 2 に示 す。菌株数は 86 で, 内訳は頻度の高い順に Escherichia

\section{検出菌株 (2014年-2018年) $\mathrm{N}=210$}

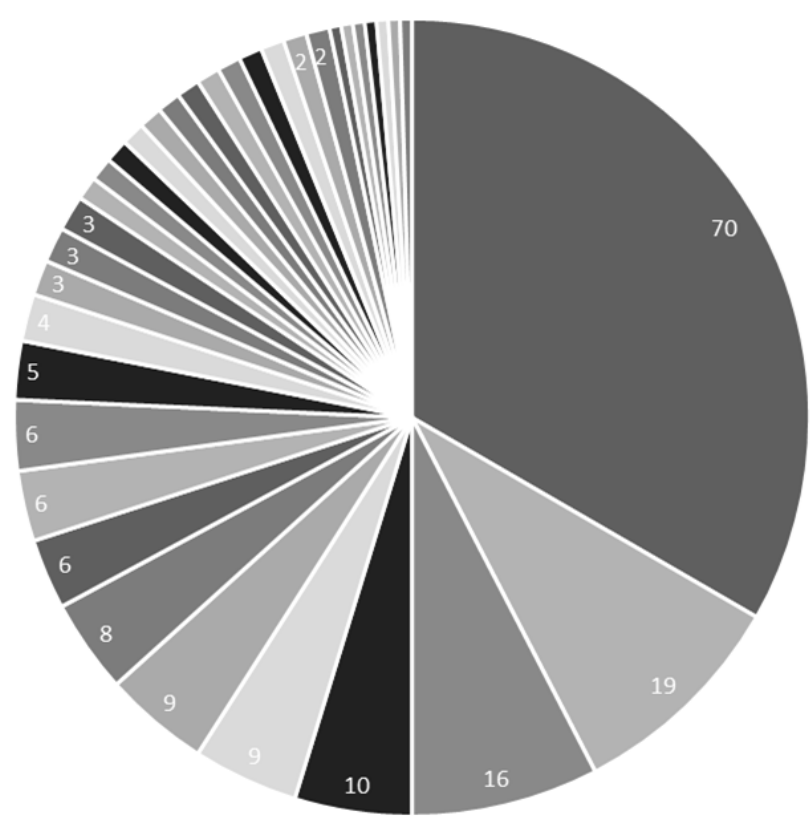

- Escherichia coli

- Staphylococcus epidermidis

ロコアグラーゼ陰性 Staphylococcus(CNS)

- Staphylococcus aureus(MRSA)

- Clostridium perfringens(ウェルシュ菌)

- Klebsiella pneumoniae

- Staphylococcus aureus $\beta$-lactamase $(+)$

- Proteus mirabilis

- Pseudomonas aeruginosa(緑膿菌)

- $\beta$-haemolytic Streptococcus(G群溶連菌)

- Bacteroides fragilis

- Streptococcus agalactiae(B群溶連菌)

= Citrobacter diversus

- Citrobacter freundii

- Staphylococcus capitis

- Bacillus sp.

- Candida tropicalis

- Clostridium sp.

- Enterobacter aerogenes

- Lactobacillus sp

- Morganella morganii

- Peptostreptococcus sp.

- Providencia sp

- Staphylococcus caprae

- Staphylococcus simulans

- Streptococcus constellatus

- Streptococcus oralis

- Streptococcus pyogenes(A群溶連菌)

- Bacteroides thetaiotaomicron

- Candida glabrate

- Corynebacterium sp

- Corynebacterium striatum

Enterococcus faecium(腸球菌)

Salmonella sp.血清型07群

- 偏性嫌気性無芽胞グラム陽性桿菌

図 1 検出された菌株（全期間） 
環境感染誌 Vol. 36 no. 1, 2021

表 2 採血部位による比較 $(n=800)$

\begin{tabular}{|c|c|c|c|c|}
\hline & & $\begin{array}{c}\text { 鼠径部 } \\
755\end{array}$ & $\begin{array}{l}\text { 上肢 } \\
45\end{array}$ & $\mathrm{P}$ 值 \\
\hline 年齢 & & $86[80,90]$ & $68[30,82]$ & $<0.01$ \\
\hline \multirow[t]{2}{*}{ 性別 } & 男性 & 396 & 25 & 0.43 \\
\hline & 女性 & 352 & 17 & \\
\hline \multicolumn{2}{|c|}{ 複数セット（\%) } & 748 (99.1) & $44(97.8)$ & 0.37 \\
\hline \multicolumn{2}{|c|}{ 陽性セット数 } & 183 & 1 & \\
\hline \multicolumn{2}{|c|}{ 陽性率（\%） } & 24.2 & 2.2 & $<0.001$ \\
\hline \multicolumn{2}{|c|}{ 污染セット数 } & 42 & 0 & \\
\hline \multicolumn{2}{|c|}{ 污染率（\%） } & 5.6 & 0 & 0.16 \\
\hline
\end{tabular}

coli (56\%), methicillin-resistant Staphylococcus aureus (MRSA) (5\%), Klebsiella pneumoniae (3\%), Bacteroides fragilis (3\%), Citrobacter diversus (Citrobacter koseri）（3\%）であり，污染率の低下と合致して，主な 污染菌であるStaphylococcus epidermidis, coagulase negative Staphylococcus (CNS) の検出割合は減少し ていた.

年齢は中央値と四分位範囲（括弧内）を表す。

表 3 鼠径部採血群 時期による比較 $(n=755)$

\begin{tabular}{|c|c|c|c|}
\hline & 2014～2015年 & 2016 年～2018年 & $\mathrm{P}$ 值 \\
\hline ガイドライン遵守消毒法 & $(-)$ & $(+)$ & \\
\hline 検体数 & 342 & 413 & \\
\hline 年齢 & $86[81,90]$ & $85[78,90]$ & $<0.01$ \\
\hline 性別 & 188 & 212 & 0.34 \\
\hline 女性 & 154 & 201 & \\
\hline 複数セット数（\%） & $337(98.5)$ & $411(99.5)$ & 0.25 \\
\hline 陽性セット数 & 106 & 77 & \\
\hline 陽性率（\%） & 31.0 & 18.6 & $<0.01$ \\
\hline 污染セット数 & 35 & 7 & \\
\hline 污染率（\%） & 10.2 & 1.7 & $<0.01$ \\
\hline
\end{tabular}

年齢は中央値と四分位範囲（括弧内）を表す.

表 4 鼠径部採血群の 2016 年 2018 年間の比較 $(n=413)$

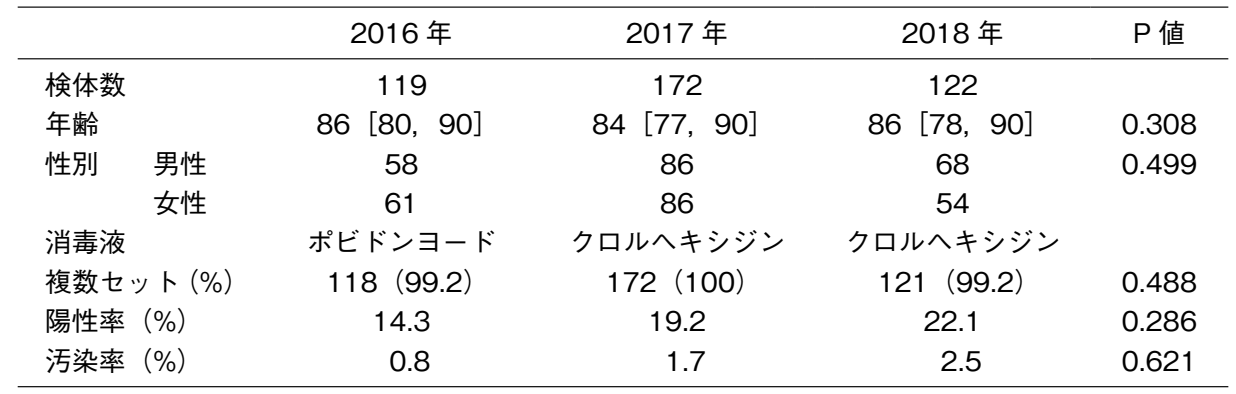

年齢は中央値と四分位範囲（括弧内）を表す.

表 52016 年〜 2018 年における鼠径部採血群と上肢採血群の比較 $(n=$ 439)

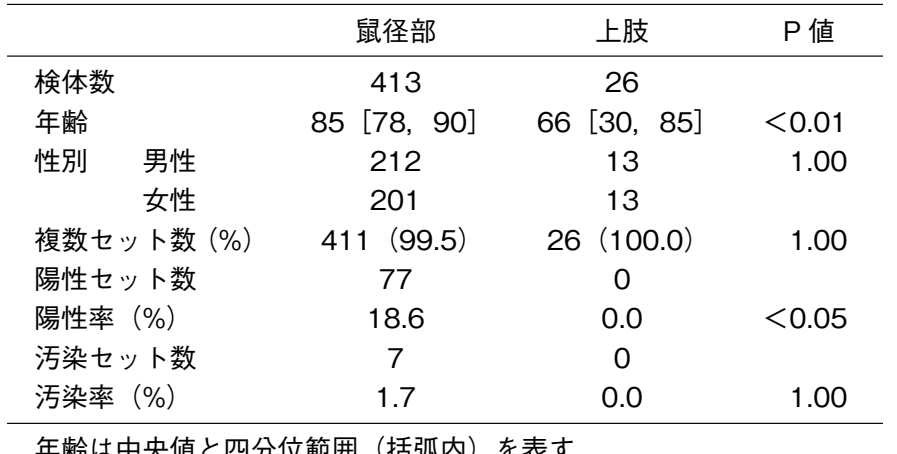

年齢は中央值と四分位範囲（括弧内）を表す。 

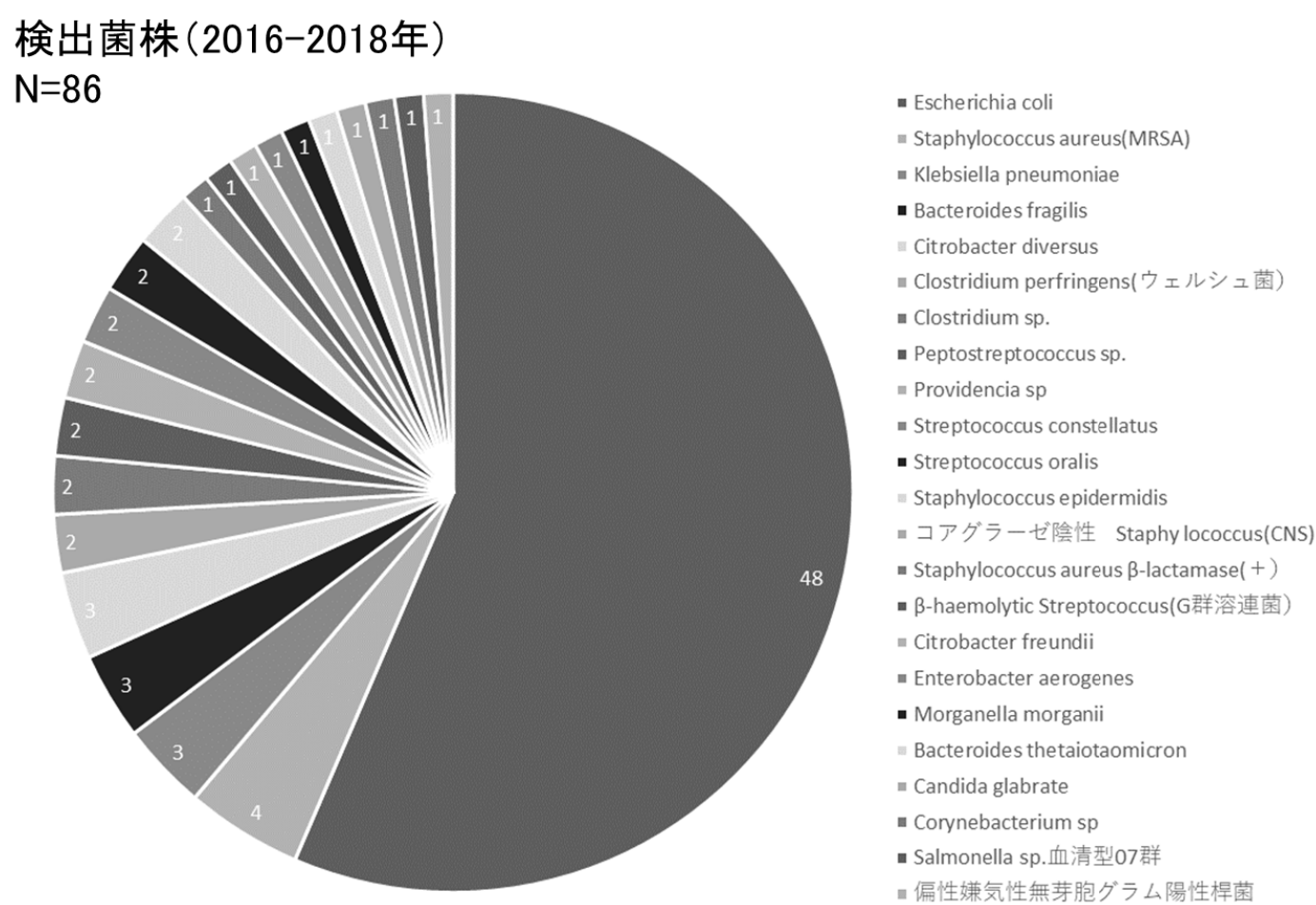

図 2 検出された菌株（2016 年から 2018 年）

\section{4. 考察}

（1）ガイドラインに準じた皮膚消毒方法で，鼠径部 からの污染率は軽減できるか

本研究結果から，ガイドラインに準じた消毒方法によ り鼠径部からの血液培養採血のコンタミネーションは約 $83 \%$ 減少し，且つ污染率は $1.7 \%$ で適正範囲を達成でき る事が示唆された。また，鼠径部採血の污染率は上肢採 血に比べ污染率が高い傾向ではあったが有意差は認めら れなかった。これまでは「鼠径部からの血液培養採血は コンタミネーションが増える」というのが一般的な考え 方であったが, 今回の研究結果は, 鼠径部からの血液培 養採血であっても, ガイドラインに準じた適切な皮膚消 毒が行われれば適正範囲内の污染率に抑える事ができる 事を示唆している．高齢患者では上肢での採血で充分な 検体量が得られにくい事を考えると, これは有用な知見 である。

本研究では特定の医師 1 名が 2014-18 年に経験した症 例を対象としている．そのため(1)症例を経験する事での $\mathrm{A}$ 医師の手技の上達, (2)採血器具の変更, (3)対象となっ た患者背景の経時的変化，などが結果に影響を与えると 考えられる。この中で(3)の対象患者背景については, 2014-15 年と 2016-18 年の患者で性別年齢に大きな差は 見られず，また患者背景を均てん化するために充分な症 例数を収集している. (2)については器具の変更は行って いない. そのため(1)の要因あるいは研究目的を知った上 で実施する場合に仮説に合うように振る舞おうとする
A 医師にかかるバイアスが影響している可能性が最も 慎重に考慮すべき因子となる。このため, 今回の研究で はすでに充分な手技の訓練を積んでおり，2014年時点 で血液培養採血に充分熟練していた A 医師の採取検体 を研究対象とし選定した. 研究期間を通じて手技的に安 定している事は，上肢における採血で污染率・陽性率と も極めて低く抑えられている事 (污染率 : 0\%, 陽性率 : 2.2\%）から推測できる。 また，本研究は後方視的なデザ インであって，採血実施時に本研究が企図されていたも のではない事から，本研究実施に伴って A 医師に余分 なバイアスがかかる余地はなかったと考える．このよう な考察から, 2016 年以前と以降における鼠径部採血の 污染率の変化は，やはり消毒法の変更によるところが大 きいと推測できる。しかし，いずれにしても，本研究が $\mathrm{A}$ 医師 1 名に限った検証結果である事は研究限界であ る. 当院のような規模の病院で, 多数の医師を用いた検 証を短期間に実施する事は困難であるが，今後対象とな る医師数を増やしてより確かな結果を得る事を目標とし たい.

\section{（2）アルコール綿清拭による効果について}

今回，ガイドラインに準じた消毒方法導入後に污染率 が適正範囲まで有意に低下し，その後消毒液をポビドン ヨードからクロルヘキシジンに変更しても污染率に有意 差は生じなかった事を踏まえると, 適正範囲内の污染率 達成に大きく影響している因子は，まず単包式 $70 \%$ 工 夕ノール綿で血液採取部位皮膚表面の污れが十分に落ち 
るまで繰り返し擦過してから皮膚消毒を実施する事では ないかと考えられる. 先行研究の中には, 消毒法を単包 化式アルコール綿で消毒するのみとしても適正範囲内の 污染率を達成している報告もある ${ }^{4,5.7)}$.

この報告が真実だとすると, 本研究で実施しているガ イドラインに準じた消毒方法は「過剩」とも取れる。し かしこれらの報告では採血部位の記載が無く, 鼠径部採 血がどの程度の数含まれていたのか不明である。この点 から, 単包化式アルコール綿のみでの消毒を鼠径部採血 に一般化する事は現時点では早計と思われる. 今後もし 単包化式アルコール綿消毒のみに消毒方法を簡素化して も鼠径部採血で同等の污染率低減が達成できる事を証明 できれば，消毒方法の費用対効果の観点から有用である. 今後の検証が待たれる.

\section{6. 結 語}

鼠径部からの血液培養採血は上肢に比べてコンタミ ネーションが増える傾向はあるが，ガイドラインに準じ た適切な皮膚消毒が行われれば適正範囲内の污染率に抑 える事が可能となる，消毒前に単包化式 70\% エタノー ル綿で血液採取部位皮膚表面の污れが十分に落ちるまで 繰り返し擦過する事が, 污染率軽減のための有力な方策 であると示唆される。

謝 辞: 本研究は, 島根大学地域包括ケア教育研究センター (Center for Community-based Health Research and Education : CoHRE) の運営プロジェクトである Academic Knowledge Network（AKN） in Shimaneの支援を受け，論文化を行った。この 場を借りてお礼申し上げる.

利益相反自己申告：申告すべきものなし．

\section{文献}

1) Ellen Jo Baron, Melvin P. Weinstein, W. Michael Dunne,
Jr., Pablo Yaguspsky, David F. Welch, Donna M Wilson, 他：松本哲哉, 満田年宏訳, Cumitech 血液培養検査ガイド ライン, 第 4 版, 医歯薬出版, 東京, 2007. p. 60.

2）日本臨床微生物学会：血液培養検査ガイド, 第 1 版, 南江 堂, 東京, 2013. p. 15, p. 125-8.

3）大曲貴夫，高倉俊二，松村康史，杉山知代，竹下 望，高 橋真菜美, 他 : 日本の病院における血液培養採取状況およ び陽性率の実態調査一パイロットスタディ。日臨微生物誌 2012; 22(1): 13-9.

4) Kiyoyama Tomonori, Tokuda Yasuharu, Shiiki Soichi, Hachiman Teruyuki, Shimasaki Teppei, Endo Kazuo: Isopropyl alcohol compared with isopropyl alcohol plus povidone-iodine as skin preparation for prevention of blood culture contamination. Journal of clinical microbiology 2009; 47: 54-8.

5）松村康史, 清水恒広, 林彰彦：地域中核病院に扔ける血 液培養 2 セット採取促進活動と培養陽性率の増加. 日臨微 生物誌 2010; 20(3): 169-76.

6) 岩田一美, 杉山八寿子, 岡部ゆかり, 羽山祐子, 黒山祥文 : 当院に扔ける過去 5 年間の血液培養実施状況. 静岡赤十字 病院研究報= Journal of Japanese Red Cross Shizuoka Hospital 2013; 33: 17-22.

7）新後閑俊之, 武谷洋子, 井川沙希子, 小林寿夫, 宮前正憲, 安野朝子：当院 Infection Control Teamによる血液培養の 複数セット採取推奖活動の成果. 日本環境感染学会誌 2016; 31(6): 382-9.

8）近藤誠吾, 小椋友美, 大久保幸世, 渡辺 光, 四方 哲, 竹 村洋典：血液培養で鼠径部から採血を行うとコンタミネー ションは増加するのか？ 第 8 回日本プライマリ・ケア連 合学会学術大会 一般演題 (口演) 2017.

9) Kanda Yoshinobu: Investigation of the freely available easy-to-use software 'EZR' for medical statistics. Bone marrow transplantation 2013; 48: 452 doi: 10.1038/ bmt.2012.244.

10) Keri K. Hall, Jason A. Lyman: Updated review of blood culture contamination. Clinical microbiology reviews 2006; 19: 788-802.

11）文部科学省 厚生労働省：人を対象とする医学系研究に関 する倫理指針（平成 29 年 2 月 28 日一部改正）：https://w ww.mhlw.go.jp/stf/seisakunitsuite/bunya/hokabunya/ken kyujigyou/i-kenkyu/index.html : 2018 年 3 月 7 日現在

〔連絡先：`693-0021島根県出雲市塩治町 1536-1 出雲市民病院家庭医療科 高橋賢史 E-mail: takasato9733@gmail.com] 


\title{
The Disinfection Method Recommended in the Guideline Reduced Contamination Rate in Blood Cultures from the Groin Area - Evaluation using Blood Culture Performed by One Skillful Physician
}

\author{
Satoshi TAKAHASHI
}

\author{
Izumo Medical Cooperative The Izumo-Shimin Hospital, Department of Family Medicine
}

\begin{abstract}
Purpose: Blood culture guidelines suggest that a positive rate of $5 \%$ to $15 \%$ and a contamination rate of $2 \%$ to $3 \%$ or less are appropriate. It is said that blood collection from the groin area increases contamination; however, in our hospital, blood collection from the groin area is predominantly performed. From 2016, we followed the disinfection method according to the guideline and determined whether the contamination from the groin area can be reduced. In order to eliminate the difference in procedures between individuals, only the samples collected by one physician were taken for verification.

Method: From 2014 to 2019, we conducted descriptive statistics and past-origin cohort studies on blood culture conducted by one doctor among blood cultures submitted at the Izumo-Shimin Hospital.

Results: Eight hundred sets were analyzed. The blood collection was done $94.4 \%$ in the groin area, 5.6\% in the upper limbs, and the collection rate for multiple sets was $99.0 \%$. From 2016, when the disinfection method was changed according to the guidelines, both the positive rate and the contamination rate of blood collection from the groin area decreased, and the contamination rate of blood collection from the groin area from 2016 to 2018 was $1.7 \%$. The contamination rate of blood collection from the upper limb was $0 \%$, but no significant difference was observed.

Discussion: Although blood culture blood collection from the groin area tends to increase contamination, it is considered that a contamination rate within the appropriate range is possible if proper skin disinfection according to the guidelines is performed.
\end{abstract}

Key words: blood culture, contamination, contamination rate, blood collection site, groin area 